\title{
Dissemination of Class 1 Integron among Different Multidrug Resistant Pseudomonas aeruginosa Strains
}

\author{
Zahra Salimizadeh \\ Department of Microbiology, Faculty \\ of Bioscience, Islamic Azad \\ University, North Tehran Branch, \\ Tehran, Iran \\ Seyed Masoud Hashemi Karouei \\ Department of biology, Babol Branch \\ Islamic Azad University, Babol, Iran \\ Farzaneh Hosseini \\ Department of Microbiology, Faculty \\ of Bioscience, Islamic Azad \\ University, North Tehran Branch, \\ Tehran, Iran \\ Corresponding author: Farzaneh \\ Hosseini \\ Tel: 09128279244 \\ Email: farzaneh953@yahoo.com \\ Address: Islamic Azad University, \\ North Tehran Branch, Tehran, Iran \\ Received : 02 Mar 2018 \\ Revised: 01 Apr 2018 \\ Accepted: 21 Apr 2018 \\ Zahra Salimizadeh 0000-0002-5148-4354 \\ Farzaneh Hosseini 0000-0001-9344-1507
}

\author{
ABSTRACT \\ Background and objectives: The present study was conducted to detect class 1 \\ integrons and evaluate antibiotic susceptibility patterns among clinical isolates of $P$. \\ aeruginosa.
}

Methods: Sixty clinical samples from blood, tracheal wounds, burns and urinary tract infections were collected from three general hospitals in Tehran, Iran. Culture of specimens was performed on common bacteriological culture media. Bacteria were identified based on mobility, pigment production, growth at $42{ }^{\circ} \mathrm{C}$, and oxidase and catalase tests. 0verall, 21 P. aeruginosa strains were isolated. Antimicrobial susceptibility of was evaluated via the disk diffusion method (Kirby-Bauer) according to the CLSI guidelines. Presence of the intIl, sull, aadA2 and $a a d B$ gene cassettes was investigated using PCR. The collected data were analyzed using SPSS software (version 21).

Results: The most effective antimicrobial agents against P. aeruginosa isolates were tetracycline and gentamicin. All $P$. aeruginosa isolates were multidrug resistant. Moreover, the intll, sull, aadA2 and $a a d B$ genes were found in $90.5 \%, 90.5 \%, 47.6 \%$ and $19 \%$ of the P. aeruginosa isolates, respectively.

Conclusion: The results indicate that the presence of $a \mathrm{adB}$, aadA2 and sull gene cassetes may play an important role in the dissemination of antimicrobial resistance determinants.

Keywords: Pseudomonas aeruginosa, integron, multidrug resistance. 


\section{INTRODUCTION}

Pseudomonas aeruginosa is as a common nosocomial pathogen, which is naturally resistant to many antimicrobial agents. Several resistance mechanisms have been identified in this pathogen, including acquisition of resistance-encoding genes through mobile genetic elements $(1,2)$. These elements include integrons capable of integrating and mobilizing gene cassettes, most of which contain resistance-encoding genes. To date, nine classes of integrons have been recognized among which, class 1 integrons are the most prevalent among $P$. aeruginosa. Class 1 integrons located in plasmids and transposons are of particular importance since they can undergo horizontal transfer and contribute to rapid dissemination of antibiotic resistance genes among bacterial isolates (3).

Integrons may play a major role in the dissemination of multidrug resistance (MDR) genes in Gram-negative bacteria (4). The class 1 integron usually consists two conserved segments (CS) flanking the antibioticresistance gene cassette(s). The 5'-CS contains the intIl gene, an attI recombination site, and a strong promoter (5). The intI gene encodes integrase, which inserts gene cassettes at the attI site (6). The 3'-CS normally carries the antiseptic-resistance gene qacEDl and the sulfonamide-resistance gene sul. On the other hand, the gene cassette is a small, mobile genetic element consisting of a single gene and a recombination site called the 59-base element $(5,7)$. More than 60 gene cassettes containing different resistance genes have been identified in Gram-negative bacilli (8), conferring resistance to different families of antibiotics such as aminoglycosides, $\beta$ lactams, chloramphenicol, trimethoprim and more recently to erythromycin (9) and rifampicin (10).

Resistance to various antibiotics is common among $P$. aeruginosa isolates in many parts of the world, including Iran (11-13). However, there is a relative paucity of data on integronassociated gene cassettes among MDR $P$. aeruginosa strains, particularly in developing countries. Aminoglycosides have been widely used for the treatment of $P$. aeruginosa infections, but increasing number of resistant strains have been reported in the recent years. Resistance to aminoglycosides in $P$. aeruginosa is primarily mediated by aminoglycoside - modifying enzymes including aminoglycoside phosphotransferases, acetyltransferases and nucleotidyl transferases (6). The genes encoding for these enzymes are often located on plasmids or transposons, enabling their rapid dissemination in a wide variety of bacterial species (14).

The aadA2 gene encoding aminoglycoside adenyltransferase confers resistance to streptomycin and spectinomycin (15), whilst $a a d B \quad$ encoding aminoglycoside adenylyltransferase confers resistance to kanamycin, tobramycin and gentamicin (16). Given the above, this study was conducted to evaluate antibiotic susceptibility patterns and presence of class 1 integrons and the $a a d B$, aadA2 and sull gene cassetes among $P$. aeruginosa isolates.

\section{MATERIAL AND METHODS}

This study was carried out in the microbiology laboratory of Department of Microbiology at Islamic Azad University, North Tehran Branch (Iran) during April 2012January 2013. Sixty samples from blood, tracheal wounds, burns and urinary tract infections were collected from three general hospitals in Tehran. The samples were immediately cultured on MacConkey agar (Merck, Germany) and incubated at $37{ }^{\circ} \mathrm{C}$ for 18-24 hours. Standard microbiological tests including Gram staining, oxidase test, catalase test, citrate test, urea test, nitrate test, gelatin hydrolysis test, indole production test, methyl red and Voges-Proskauer test and growth at 42 ${ }^{\circ} \mathrm{C}$ were performed for identification of the $P$. aeruginosa strains. All isolates were kept at $20{ }^{\circ} \mathrm{C}$ until used (17). Antimicrobial susceptibility testing was performed using the disk agar diffusion method according to the CLSI recommendations (2013 M100-S23) (18). In brief, an inoculum of $10^{8} \mathrm{cfu} / \mathrm{mL}$ bacteria equivalent to $0.5 \mathrm{McFarland}$ was inoculated on Mueller-Hinton agar (Merck, Germany). Subsequently, discs containing the following antibiotics were added to the plates: ampicillin $(10 \mu \mathrm{g})$, cefixime $(5 \mu \mathrm{g})$, cephalothin $(30 \mu \mathrm{g})$, nalidixic acid $(30 \mu \mathrm{g})$, carbenicillin $(100 \mu \mathrm{g})$, clindamycin $(2 \mu \mathrm{g})$, chloramphenicol $(30 \mu \mathrm{g})$, trimethoprimsulfamethoxazole $(25 \mu \mathrm{g})$, ciprofloxacin (5 $\mu \mathrm{g})$, norfloxacin $(10 \mu \mathrm{g})$, gentamicin (10 $\mu \mathrm{g})$, amikacin $(30 \mu \mathrm{g})$, streptomycin $(10 \mu \mathrm{g})$ and tetracycline $(30 \mu \mathrm{g})$ (Pad-Tan Teb Co., 
Tehran, Iran). The plates were incubated at 37 ${ }^{\circ} \mathrm{C}$ for 24 hours. Diameter of inhibition zone was measured based on the the CLSI guidelines. P. aeruginosa ATCC 27853 was used as the quality control strain.

DNA was extracted using a DNA isolation kit (MBST, Iran) according to the manufacturer's instructions. A single colony of each isolate was inoculated into $10 \mathrm{~mL}$ of Luria-Bertani broth (Merck, Germany). After 18 hours, two $\mathrm{mL}$ of each sample was used for DNA extraction using a commercial kit. Briefly, the samples were lysed in $180 \mu 1$ lysis buffer, and proteins were degraded with $20 \mu$ l proteinase $\mathrm{K}$ at $55{ }^{\circ} \mathrm{C}$ for $10 \mathrm{~min}$. After adding $360 \mu \mathrm{l}$ of binding buffer, each sample was incubated at $70{ }^{\circ} \mathrm{C}$ for $10 \mathrm{~min}$. Then, $270 \mu \mathrm{l}$ of ethanol (96\%) were added and the solution was vortexed. The content of tubes was transferred to a MBST-column. The MBST-column was centrifuged and washed twice with $500 \mu \mathrm{l}$ of washing buffer. DNA was eluted from the carrier using $100 \mu \mathrm{l}$ of elution buffer. After removing the DNA, the samples were stored at $-20^{\circ} \mathrm{C}$ until PCR analysis.

All PCR reactions were carried out using a 25 $\mu \mathrm{L}$ reaction solution containing $18.5 \mu \mathrm{L}$ of water, $2 \mu \mathrm{L}$ of a $10 \mathrm{X}$ reaction buffer, $0.3 \mu \mathrm{L}$ of
$\mathrm{MgCl}_{2}(50 \mathrm{mM}), 1 \mu \mathrm{L}$ of dNTPs $(10 \mathrm{mM}), 1$ $\mu \mathrm{L}$ of each primer $(50 \mathrm{mM}), 0.2 \mu \mathrm{L}$ of Taq DNA polymerase (mi-E8001S, Metabion, Planegg/Martinsried, Germany), and $1 \mu \mathrm{L}$ of template DNA. The presence of class 1 integrons was evaluated by PCR using primers specific for the integron-integrase gene (intI1). All isolates were screened for the presence of intI1 (19), aadB (20), aadA2 (21) and sull (21). Table 1 represents the PCR annealing temperature, primer (Metabion, Germany) sequences and size of amplicons. The reaction was performed in a thermocycler (Eppendorf Mastercycler®, MA) using the following thermocycling conditions: initial denaturation at $95{ }^{\circ} \mathrm{C}$ for $5 \mathrm{~min}, 30$ cycles of denaturation at $95{ }^{\circ} \mathrm{C}$ for $30 \mathrm{~s}$, annealing for $60 \mathrm{~s}$ and extension at $72{ }^{\circ} \mathrm{C}$ for 60 seconds, and final extension at $72{ }^{\circ} \mathrm{C}$ for $10 \mathrm{~min}$ (Table 1).

Four $\mu \mathrm{L}$ of $\mathrm{PCR}$ products were electrophoresed on $2 \%$ agarose gel in a TAE buffer at $45 \mathrm{~V}$. After ethidium bromide staining for $15 \mathrm{~min}$, the results were visualized and photographed using a gel documentation system. DNA molecular weight marker (300 bp $-10000 \mathrm{bp}$ ) was used as the standard (miE8201 Metabion, Planegg/Martinsried, Germany).

Table 1- The sequence of primers, annealing temperatures $\left({ }^{\circ} \mathrm{C}\right)$ and size of amplicons for each target gene

\begin{tabular}{|c|c|c|c|c|c|}
\hline Target gene & Forward & Reverse & $\begin{array}{c}\text { Annealing } \\
\text { Temperatu } \\
\text { re } \\
\left({ }^{\circ} \mathrm{C}\right) \\
\end{array}$ & $\begin{array}{c}\text { Size of } \\
\text { amplicon } \\
\text { (bp) }\end{array}$ & Reference \\
\hline intI1 & 5'-ACGAGCGCAAGGTTTCGGT-3' & 5'-AAAGGTCTGGTCATACATG-3' & 53 & 565 & 19 \\
\hline sul1 & 5'-TCACCGAGGACTCCTTCTT-3' & 5'-AATATCGGGATAGAGCGCA-3' & 55 & 317 & 21 \\
\hline $\operatorname{aadA2}$ & $\begin{array}{c}5^{\prime} \text {-TGTTGGTTACTGTGGCCGTA- } \\
3^{\prime}\end{array}$ & $\begin{array}{c}5^{\prime} \text {-GATCTCGCCTTTCACAAAGC- } \\
3^{\prime}\end{array}$ & $\mathbf{5 0}$ & 623 & 21 \\
\hline aadB & $\begin{array}{c}5^{\prime} \text {-ATGGACACAACGCAGGTCGC- } \\
3^{\prime}\end{array}$ & $\begin{array}{c}5^{\prime} \text {-TTAGGCCGCATATCGCGACC- } \\
3^{\prime}\end{array}$ & 55 & 534 & 20 \\
\hline
\end{tabular}

Data were analyzed with SPSS (version 21) using Chi-Square test. A P-value of less than 0.05 was considered as statistically significant.

\section{RESULTS}

Gram-negative, catalase-positive and oxidase-positive bacilli able to grow at $42{ }^{\circ} \mathrm{C}$ were identified as $P$. aeruginosa strains. Overall, $21 P$. aeruginosa strains were identified among different samples. The strains were able to produce acid from glucose and were positive in the urea test, gelatin hydrolysis test, citrate test, nitrate reduction. The strains were found negative in the indole production, methyl red and Voges-Proskauer tests (17).

All $P$. aeruginosa isolates were $100 \%$ resistant to ampicillin, cefixime, cephalothin, nalidixic acid, clindamycin and chloramphenicol. The most effective antimicrobial agent against $P$. aeruginosa was tetracycline (Table 2).

The class 1 integrons was found in $19(90.5 \%)$ $P$. aeruginosa isolates. The sull, aadA2 and $a a d B$ genes were detected in $19(90.5 \%), 10$ (47.6\%) and $4(19 \%) P$. aeruginos isolates, respectively. The aadA2 gene was present in $10(52.6 \%)$ integron-positive $P$. aeruginosa strains but absent in integron-negative strains. Moreover, the $a a d B$ gene was present in 4 (21\%) integron-positive $P$. aeruginosa strains but absent in integron-negative strains. 
Figure 1- PCR amplification of the class I integron intI1 gene in P. aeruginosa isolates. Column M: DNA size marker (mi-E8201), columns 1-3: negative isolates, columns 4-6: positive isolates (clinical isolates of $P$. aeruginosa), column 7: negative control

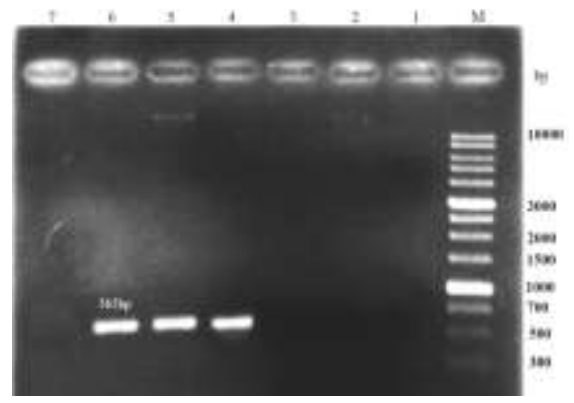

Table 2- Association between antibiotic resistance pattern and presence of integrons in $P$. aeruginosa isolates

\begin{tabular}{|c|c|c|c|c|c|c|c|}
\hline \multirow[t]{2}{*}{ Antibiotic } & \multicolumn{2}{|c|}{$\begin{array}{c}\text { Antibiotic susceptibility } \\
(n=21)\end{array}$} & \multicolumn{2}{|c|}{$\begin{array}{c}\text { Integron-positive }(n= \\
19)\end{array}$} & \multicolumn{2}{|c|}{ Integron-negative ( $n=2)$} & \multirow[t]{2}{*}{$\begin{array}{c}P \text { P- } \\
\text { value }\end{array}$} \\
\hline & *Resistant (\%) & $\begin{array}{l}\text { Sensitive } \\
(\%)\end{array}$ & $\begin{array}{c}\text { Resistant } \\
(\%)\end{array}$ & $\begin{array}{l}\text { Sensitive } \\
(\%)\end{array}$ & $\begin{array}{c}\text { Resistant } \\
(\%)\end{array}$ & $\begin{array}{l}\text { Sensitive } \\
(\%)\end{array}$ & \\
\hline Gentamicin & $18(85.7)$ & $3(14.3)$ & $17(89.5)$ & $2(10.5)$ & $1(50)$ & $1(50)$ & 0.129 \\
\hline Amikacin & $16(76.2)$ & $5(23.8)$ & $15(78.9)$ & $4(21.1)$ & $1(50)$ & $1(50)$ & 0.361 \\
\hline Streptomycin & $18(85.7)$ & $3(14.3)$ & $18(94.7)$ & $1(5.3)$ & $\mathbf{0}$ & $\mathbf{0}$ & 0.000 \\
\hline Tetracycline & $15(71.4)$ & $6(28.6)$ & 14 (73.7) & $5(26.3)$ & $1(50)$ & $1(50)$ & 0.481 \\
\hline Carbenicillin & $18(85.7)$ & $3(14.3)$ & $17(89.5)$ & $2(10.5)$ & $1(50)$ & $1(50)$ & 0.12 \\
\hline Ciprofloxacin & $17(80.9)$ & $4(19.1)$ & $17(89.5)$ & $2(10.5)$ & $\mathbf{0}$ & $\mathbf{0}$ & 0.002 \\
\hline Norfloxacin & $17(80.9)$ & $4(19.1)$ & 17 (89.5) & $2(10.5)$ & $\mathbf{0}$ & $\mathbf{0}$ & 0.002 \\
\hline $\begin{array}{l}\text { Trimethoprim- } \\
\text { Sulfamethoxazole }\end{array}$ & $20(95.2)$ & $1(4.8)$ & $19(100)$ & $\mathbf{0}$ & $1(50)$ & $1(50)$ & 0.002 \\
\hline
\end{tabular}

*Number of resistant and intermediate isolates according to the CLSI guidelines

\section{DISCUSSION}

In this study, we evaluated antibiotic susceptibility pattern and presence of class 1 integrons along with associated gene cassetes in $P$. aeruginosa isolates. The results showed that all isolates were MDR. Multiple antibiotic resistance is defined as resistance to more than three antibiotics from different classes (22). The MDR rate in our study was higher than that in previous studies in Iran. Study of Mirsalehian et al. in Tehran reported that $87.05 \%$ of $P$. aeruginosa isolates were MDR (23).

The emergence of resistant $P$. aeruginosa strains has limited the antibiotic treatment options, leading to an increased risk of treatment failure. These results might be due to inadequate use of antimicrobial drugs in different clinical settings and the spread of resistance determinants.

Multiple classes of integrons have been identified in Gram-negative bacteria according to their distinct integrase genes. Class 1 integrons are the most prevalent in clinical isolates and carry single or multiple gene cassettes (24). PCR detection of the integrase gene has some advantages over the PCR detection of integron cassette for screening of integrons because it is designed to give a small product, which is easily amplified. PCR detection of the integron cassette can give false negative results when integrons are present, the cassette array is difficult to amplify and cassettes are absent. PCR detection of the integrase gene is simple, reliable and easy to perform (25).

We found high frequency of intIl among $P$. aeruginosa isolates. In other studies in Iran, the frequency of class 1 integrons are ranging from $27.5 \%$ to $95.7 \%$. In a study conducted by Mobaraki et al., $27.5 \%$ of Psudomonas strains contained the class 1 integrons (26). Higher rates were observed in studies of Yousefi et al. (56.3\%), Mirahsani et al. (76\%), Hosseini et al. (90\%), Hosseini Pour et al. (92\%) and Khosravi et al. (95.7\%) (27-31). The frequency of class 1 integrons was found to be $41.5 \%$ and $82 \%$ among $P$. aeruginosa isolates in Brazil and Thailand, respectively $(32,33)$. However, the frequency of class 1 integrons was very low $(4.5 \%)$ in a multicenter study in Turkey (34). The frequency of intIl in our study was similar 
to that of two other studies $(35,36)$. The sull gene that codes for sulfamethoxazole resistance is located on the 3 'conserved segment of the integron. This gene was detected in all integron-positive $P$. aeruginosa strains. In line with findings of previous studies, our results indicated that sull is strongly linked to integrons (37).

The results also showed a significant association between integrons and resistance to streptomycin, ciprofloxacin, norfloxacin and trimethoprim-sulfamethoxazole.

The significant correlation between the presence of integrons and antibiotic resistance among the MDR $P$. aeruginosa isolates suggests that integrons might be responsible for the distribution of antibiotic resistance genes among MDR strains.

Studies conducted in China and Spain reported a significant association between resistance genes and resistant to some antibiotics such as aminoglycosides, beta-lactams and quinolons $(3,38)$. In another study conducted in Iran, a significant correlation was found between the presence of integrons and resistance against ceftazidime, piperacillin and ciprofloxacin in $P$. aeruginosa isolates (39).

Aminoglycosides are highly potent, broadspectrum antibiotics with favorable properties for the treatment of life-threatening infections. The emergence of resistant strains has somewhat limited the potential of aminoglycosides in empiric therapies (40). One of the most common resistance mechanisms against aminoglycosides is the production of aminoglycoside-modifying enzymes, such as aminoglycoside acetyltransferases, aminoglycoside phosphorylases and aminoglycoside adenyltransferases (41). In this study, two aminoglycoside resistance genes were investigated; the aadA2 gene encoding an aminoglycoside adenyltransferase, which confers resistance to streptomycin and spectinomycin (42) and the $a a d B$ gene encoding an aminoglycoside adenylyltransferase, which confers resistance to gentamicin, kanamycin and tobramycin (43). In a study conducted in China, several aminoglycoside resistance genes including aadA1, aadA2, aadA5, aadA6, aadB and accA4 within the integron structures were detected among $A$. baumannii and $P$. aeruginosa strains. The most frequently detected resistance genes (aadA family) were aminoglycoside adenyltransferase-encoding genes that confer resistance to streptomycin and spectinomycin (3). In a study carried out in northwest of Iran, the aad and aac were the most common genes found in the cassettes, which are associated with resistance to aminoglycosides (26).

In this study, the $a a d A 2$ and $a a d B$ genes were present only in the integron-positive strains of $P$. aeruginosa. In addition, all $P$. aeruginosa strains with the $a a d A 2$ and $a a d B$ genes were completely resistant to streptomycin and gentamicin. However, strains without these genes showed high level of resistance to streptomycin and gentamicin. Resistance gene cassettes found in the class 1 integrons cannot cover all resistance phenotypes in this pathogen, indicating the existence of other resistance mechanisms. Several other resistance mechanisms have been reported in $P$. aeruginosa, such as multidrug efflux systems and other gene cassettes $(35,44)$. However, such mechanisms were not investigated in the present study.

\section{CONCLUSION}

Our results confirm the high prevalence of class 1 integrons and their important role in the dissemination of antimicrobial resistance genes among $P$. aeruginosa isolates. The high rate of antimicrobial resistance among $P$. aeruginosa isolates highlights the need for urgent reconsideration of antibiotics use at clinical settings. Therefore, it is important to perform antibiotic surveillance programs for appropriate empirical therapy and infection control practices. In addition, monitoring of drug resistance using gene integrase PCR is crucial for infection control planning against multidrug resistance $P$. aeruginosa in hospitals.

Nevertheless, further studies should be performed on the prevalence of integrons in other parts of the country.

\section{ACKNOWLEDGEMENTS}

The authors would like to thank the colleagues and authorities at the Islamic Azad University, North Tehran Branch who helped us in this project.

\section{CONFLICT OF INTEREST}

All authors declare that there is no conflict of interest. 


\section{REFERENCES}

1. Seward RJ, Towner KJ. Detection of integrons in worldwide nosocomial isolates of Acinetobacter spp. Clin Microbiol Infect. 1999; 5(6): 308-18. https://doi.org/10.1111/j.1469-0691.1999.tb00149.x

2. Xu Z, Li L, Shirtliff ME, Alam M, Yamasaki S, Shi L. Occurrence and characteristics of class 1 and 2 integrons in Pseudomonas aeruginosa isolates from patients in southern China. J Clin Microbiol. 2009; 47(1): 230-4. https://doi.org/10.1128/JCM.02027-08

3. Gu B, Tong M, Zhao W, Liu G, Ning M, Pan S, et al. Prevalence and characterization of class $I$ integrons among Pseudomonas aeruginosa and Acinetobacter baumannii isolates from patients in Nanjing, China. J Clin Microbiol. 2007; 45(1): 241-3. https://doi.org/10.1128/JCM.01318-06

4. Mazel D, Dychinco B, Webb VA, Davies J. Antibiotic resistance in the ECOR collection: integrons and identification of a novel aad gene. Antimicrob Agents Chemother. $\quad 2000 ; \quad 44(6)$ : 1568-74. https://doi.org/10.1128/AAC.44.6.1568-1574.2000

5. Stokes H, Hall R. A novel family of potentially mobile DNA elements encoding site-specific gene-integration functions: integrons. Mol Microbiol. 2006; 3(12): 166983. https://doi.org/10.1111/j.1365-2958.1989.tb00153.x 6. Mak JK. Integrons, Resistance Genes and Their Dissemination (in Gram-Negative Bacteria): School of Biotechnology \& Biomolecular Sciences, University of New South Wales. Sydney, AUSTRALIA. 2009.

7. Deng Y, Bao X, Ji L, Chen L, Liu J, Miao J, et al. Resistance integrons: class 1, 2 and 3 integrons. Ann Clin Microbiol Antimicrob. 2015; 14(1): 45. https://doi.org/10.1186/s12941-015-0100-6.

8. Hall RM, Collis CM. Antibiotic resistance in gramnegative bacteria: the role of gene cassettes and integrons. Drug Resist Updat. 1998; 1(2): 109-19. https://doi.org/10.1016/S1368-7646(98)80026-5

9. Jones ME, Peters E, Weersink A-M, Fluit A, Verhoef J. Widespread occurrence of integrons causing multiple antibiotic resistance in bacteria. The Lancet. 1997; 349(9067): $\quad 1742-3$. https://doi.org/10.1016/S01406736(05)62954-6

10. Tribuddharat C, Fennewald M. Integron-Mediated Rifampin Resistance in Pseudomonas aeruginosa. Antimicrob Agents Chemother. 1999; 43(4): 960-2.

11. Hashemizadeh Z, Bazargani A, Emami A, Rahimi M. Acinetobacter antibiotic resistance and frequency of ESBL-producing strains in ICU patients of Namazi Hospital (2008-2009). The Journal of Qazvin University of Medical Sciences. 2010; 14: 47-53.

12. Lari AR, Alaghehbandan R, Akhlaghi L. Burn wound infections and antimicrobial resistance in Tehran, Iran: an increasing problem. Ann Burns Fire Disasters. 2005; 18(2): 68

13. Taherikalani M, Maleki A, Sadeghifard N, Mohammadzadeh D, Soroush S, Asadollahi P, et al. Dissemination of class 1,2 and 3 integrons among different multidrug resistant isolates of Acinetobacter baumannii in Tehran hospitals, Iran. Iran Pol J Microbiol. 2011; 60(2): 169-74.
14. Stokes Ht, Hall RM. A novel family of potentially mobile DNA elements encoding site-specific geneintegration functions: integrons. Mol Microbiol. 1989; 3(12): $\quad 1669-83$. https://doi.org/10.1111/j.13652958.1989.tb00153.x

15. Quinteira S, Sousa JC, Peixe L. Characterization of In100, a new integron carrying a metallo- $\beta$-lactamase and a carbenicillinase, from Pseudomonas aeruginosa. Antimicrob Agents Chemother. 2005; 49(1): 451-3. https://doi.org/10.1128/AAC.49.1.451-453.2005

16. Ruiz-Martínez L, López-Jiménez L, Fusté E, Vinuesa $\mathrm{T}$, Martínez J, Vi-as M. Class 1 integrons in environmental and clinical isolates of Pseudomonas aeruginosa. Int J Antimicrob Agents. 2011; 38(5): 398402. https://doi.org/10.1016/j.ijantimicag.2011.06.016.

17. Mahon CR, Manuselis G, Lehman DC. Textbook of diagnostic microbiology. Saunders Pennsylvania; 2000.

18. Wayne P. Performance standards for antimicrobial susceptibility testing:Twenty-Third informational supplement. Clinical and Laboratory Standards Institute; 2013.

19. Xu H, Su Z, Wang S, Dai X, Chen J, Kong F, et al. Four novel resistance integron gene-cassette occurrences in bacterial isolates from Zhenjiang, China. Curr Microbiol. 2009; 59(2): 113-7. https://doi.org/10.1007/s00284-009-9405-Z

20. Hujer KM, Hujer AM, Hulten EA, Bajaksouzian S, Adams JM, Donskey CJ, et al. Analysis of antibiotic resistance genes in multidrug-resistant Acinetobacter sp. isolates from military and civilian patients treated at the Walter Reed Army Medical Center. Antimicrob Agents Chemother. 2006; 50(12): 4114-23. https://doi.org/10.1128/AAC.00778-06.

21. Randall L, Cooles S, Osborn M, Piddock L, Woodward M. Antibiotic resistance genes, integrons and multiple antibiotic resistance in thirty-five serotypes of Salmonella enterica isolated from humans and animals in the UK. J Antimicrob Chemother. 2004; 53(2): 20816. https://doi.org/10.1093/jac/dkh070

22. Falagas ME, Koletsi PK, Bliziotis IA. The diversity of definitions of multidrug-resistant (MDR) and pandrugresistant (PDR) Acinetobacter baumannii and Pseudomonas aeruginosa. J Med Microbiol. 2006; 55(12): 1619-29. https://doi.org/10.1099/jmm.0.46747-0

23. Mirsalehian A, Feizabadi M, Nakhjavani FA, Jabalameli F, Goli H, Kalantari N. Detection of VEB-1, OXA-10 and PER-1 genotypes in extended-spectrum $\beta$ lactamase-producing Pseudomonas aeruginosa strains isolated from burn patients. Burns. 2010; 36(1): 70-4. https://doi.org/10.1016/j.burns.2009.01.015

24 . Weldhagen GF. Integrons and $\beta$-lactamases - a novel perspective on resistance. Int J Antimicrob Agents. 2004; 23(6): 556-62. https://doi.org/10.1016/j.ijantimicag.2004.03.007.

25. Turton JF, Kaufmann ME, Glover J, Coelho JM, Warner M, Pike R, et al. Detection and typing of integrons in epidemic strains of Acinetobacter baumannii found in the United Kingdom. J Clin Microbiol. 2005; 43(7): 3074-82. https://doi.org/10.1128/JCM.43.7.30743082.2005 
26. Mobaraki S, Aghazadeh M, Barhaghi MHS, Memar MY, Goli HR, Gholizadeh $\mathrm{P}$, et al. Prevalence of integrons 1, 2, 3 associated with antibiotic resistance in Pseudomonas aeruginosa isolates from Northwest of Iran. 2018; 8(1): 2. doi: 10.1051/bmdcn/2018080102.

27. Yousefi S, Nahaei M, Farajnia S, Ghojazadeh M, Akhi M, Sharifi Y, et al. Class 1 integron and Imipenem Resistance in Clinical Isolates of Pseudomonas aeruginosa: Prevalence and Antibiotic Susceptibility. Iran J Microbiol. 2010; 2(3): 115.

28. Mirahsani M, Khorshidi A, Moniri R, Gilasi HR. Prevalence of Class 1 Integron, Resistance Gene Cassettes and Antimicrobial Susceptibility Profiles among Isolates of Pseudomonas aeruginosa in Iran. Open J Med Microbiol 2016; 6(02): 87. https://doi.org/10.4236/ojmm.2016.62012.

29. Hosseini SMJ, Naeini NS, Khaledi A, Daymad SF, Esmaeili D. Evaluate the Relationship Between Class 1 Integrons and Drug Resistance Genes in Clinical Isolates of Pseudomonas aeruginosa. The open microbiology journal. 2016; 10 : $188-196$. https://doi.org/10.2174/1874285801610010188

30. Hosseini Pour P, Momtaz H, Serajyan AA, Tajbakhsh E. Investigating Class I, II and III Integrons in Multidrug Resistance in Pseudomonas aeruginosa Isolated from Hospital Infections in Ahvaz. Int J Med Lab. 2015; 2(3): 168-76.

31. Khosravi $\mathrm{AD}$, Motahar $\mathrm{M}$, Montazeri EA. The frequency of class 1 and 2 integrons in Pseudomonas aeruginosa strains isolated from burn patients in a burn center of Ahvaz, Iran. PloS one. 2017; 12(8): e0183061. https://doi.org/10.1371/journal.pone.0183061.

33. Kiddee A, Henghiranyawong K, Yimsabai J, Tiloklurs M, Niumsup PR. Nosocomial spread of class 1 integron-carrying extensively drug-resistant Pseudomonas aeruginosa isolates in a Thai hospital. Int J Antimicrob Agents. 2013; 42(4): 301-6. https://doi.org/10.1016/j.ijantimicag.2013.05.009

34. Cicek AC, Saral A, Duzgun AO, Cizmeci Z, Kayman T, Balci PO, et al. Screening of Class 1 and Class 2 integrons in clinical isolates of Pseudomonas aeruginosa collected from seven hospitals in Turkey: A multicenter study. Open Journal of Medical Microbiology. 2013; 3(4): 227-233. https://doi.org/10.4236/ojmm.2013.34034

35. Poonsuk K, Tribuddharat C, Chuanchuen R. Class 1 integrons in Pseudomonas aeruginosa and Acinetobacter baumannii isolated from clinical isolates. Southeast Asian J Trop Med Public Health. 2012; 43(2): 376-84.
36. Hosseini Pour P, Momtaz H, Serajyan AA, Tajbakhsh E. Investigating class I, II and III integrons in multidrug resistance in Pseudomonas aeruginosa isolated from hospital infections in Ahvaz. International Journal of Medical Laboratory. 2015; 2(3): 168-76.

37. Levesque C, Piche L, Larose C, Roy PH. PCR mapping of integrons reveals several novel combinations of resistance genes. Antimicrob Agents Chemother. 1995; 39(1): 185-91. https://doi.org/10.1128/AAC.39.1.185.

38. Juan C, Beceiro A, Gutiérrez O, Albertí S, Garau M, Pérez JL, et al. Characterization of the new metallo- $\beta$ lactamase VIM-13 and its integron-borne gene from a Pseudomonas aeruginosa clinical isolate in Spain. Antimicrobial agents and chemotherapy. 2008; 52(10): 3589-96. https://doi.org/10.1128/AAC.00465-08.

39. Nikokar I, Tishayar A, Flakiyan Z, Alijani K, Rehana-Banisaeed S, Hossinpour M, et al. Antibiotic resistance and frequency of class 1 integrons among Pseudomonas aeruginosa, isolated from burn patients in Guilan, Iran. Iran J Microbiol. 2013; 5(1): 36-41.

40. Mingeot-Leclercq M-P, Glupczynski Y, Tulkens PM. Aminoglycosides: activity and resistance. Antimicrob Agents Chemother. 1999; 43(4): 727-37.

41. Shaw K, Rather P, Hare R, Miller G. Molecular genetics of aminoglycoside resistance genes and familial relationships of the aminoglycoside-modifying enzymes. Microbiological Reviews. 1993; 57(1): 138-63.

42. Hollingshead S, Vapnek D. Nucleotide sequence analysis of a gene encoding $a$ streptomycin/spectinomycin adenyltransferase. Plasmid. 1985; 13(1): 17-30. https://doi.org/10.1016/0147619X(85)90052-6.

43. Cameron FH, Obbink DJG, Ackerman VP, Hall RM. Nucleotide sequence of the AAD (2') aminoglycoside adenylyltransferase determinant aadB. Evolutionary relationship of this region with those surrounding aadA in R538-1 and dhfrll in R388. Nucleic Acids Res. 1986; 14(21): 8625-35. https://doi.org/10.1093/nar/14.21.8625.

44. Marchand I, Damier-Piolle L, Courvalin P, Lambert T. Expression of the RND-type efflux pump AdeABC in Acinetobacter baumannii is regulated by the AdeRS twocomponent system. Antimicrob Agents Chemother. 2004; 48(9): 3298-304. https://doi.org/10.1128/AAC.48.9.3298-3304.2004 